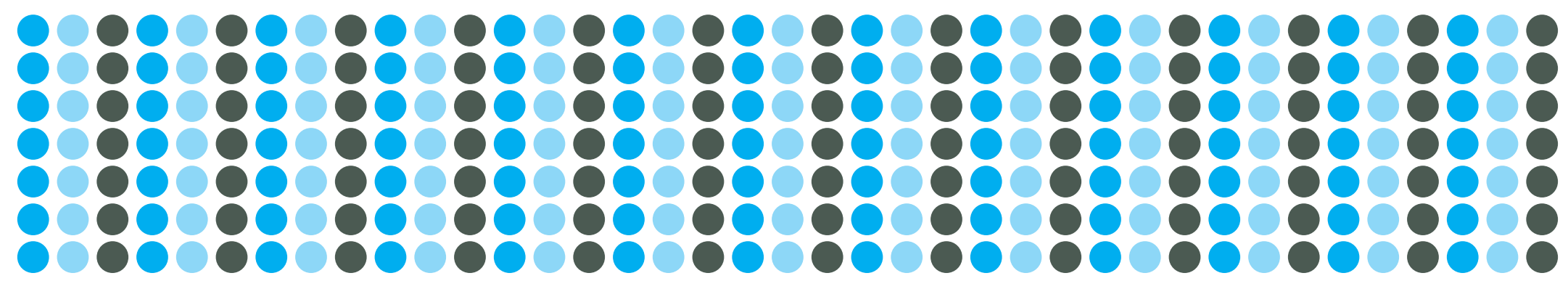

AUTHOR BIOGRAPHIES

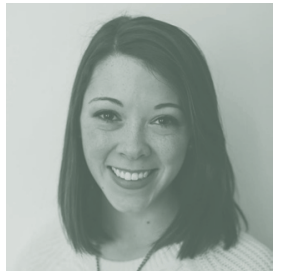

\title{
RACHEL ALDRICH
}

is a junior in the College of Arts \& Sciences majoring in English with minors in Creative Writing, American Studies, and Management and Leadership. The inspiration for her article in Elements came from her work in the American Studies minor. In addition to interning at Post Road magazine, she is a staff member for Stylus, Features editor for The Gavel, and the Music Librarian for the University Chorale of Boston College. After graduating next May, she hopes to continue on to graduate school.

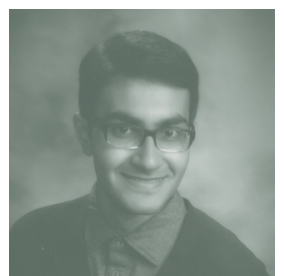

\section{SALJOOQ M. ASIF}

is a senior in the College of Arts \& Sciences, majoring in Biology and English. A member of the Arts \& Sciences Honors Program, he is also a science editor for Elements. His writing has appeared in both The Heights, the independent student newspaper of Boston College, and Dianoia, the undergraduate philosophy journal of Boston College. Asif's article was written for Professor Susan Michalczyk's senior Honors seminar, Autobiographical Novel/Memoir, which focused on the autobiographical genre in literature and film. He would like to thank Professor Susan Michalczyk for her creative guidance, as well as Professor Ronan Noone for introducing him to Ayad Akhtar's work.

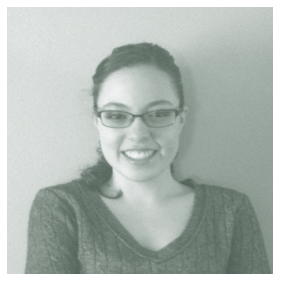

\section{DANIELLE NISTA}

is a junior, double majoring in History and French. She is a member of Alpha Sigma Nu, the National Honors Society of Jesuit Colleges and Universities, and Phi Alpha Theta, the History Honors Society. She is also a choreographer for BC Full Swing, Boston College's swing dancing team. In high school, a combined interest in tap dancing and postbellum southern history led to a research paper on the connections between minstrel shows and Hollywood musicals of the 1930s. Following this article, Danielle's interest was piqued to continue to combine two of her passions: dancing and studying the history of America before, during, and after the Civil War. She hopes to one day write a book about the full history of tap dancing.

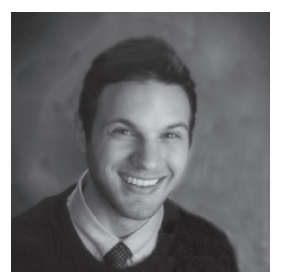

\section{DAVID QUERUSIO}

is from Millis, MA, and came to Boston College in 2012 as an English major, but quickly added a minor in Sociology. He enjoys all kinds of literature, especially contemporary works. He is interested in how literature intersects and interacts with social theories such as feminism, postcolonialism, queer theory, and Marxism. Possible future plans include graduate school. 

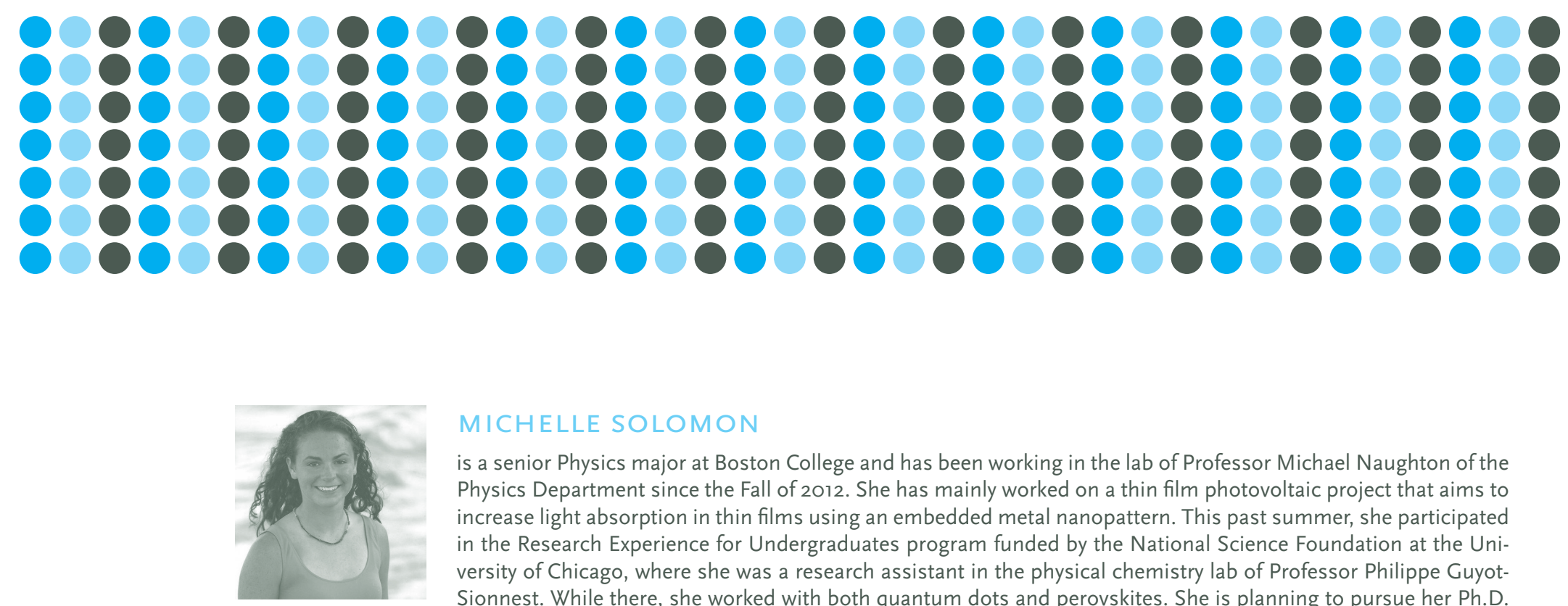

\section{MICHELLE SOLOMON}

is a senior Physics major at Boston College and has been working in the lab of Professor Michael Naughton of the Physics Department since the Fall of 2012. She has mainly worked on a thin film photovoltaic project that aims to increase light absorption in thin films using an embedded metal nanopattern. This past summer, she participated in the Research Experience for Undergraduates program funded by the National Science Foundation at the University of Chicago, where she was a research assistant in the physical chemistry lab of Professor Philippe GuyotSionnest. While there, she worked with both quantum dots and perovskites. She is planning to pursue her Ph.D. in Materials Science and Engineering after graduation.

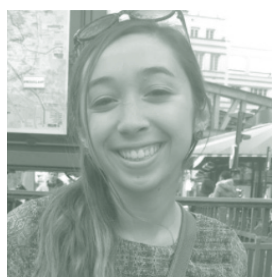

CAITLIN TOTO

is a senior in the College of Arts and Sciences, majoring in Political Science and minoring in Economics. While at Boston College, Caitlin has been an active member of 4 Boston and is currently the Co-President of Americans for Informed Democracy. Additionally, she is an Undergraduate Research Fellow for Professor Lindsey O'Rourke, researching CIA covert operations during the Cold War. Caitlin's article was written for Professor Krause's “Terrorism and Political Violence" class in the summer of 2014 and was inspired by her interest in female terrorism and Muslim minorities in Europe and Asia. She will be attending law school in the fall with a focus on either international or healthcare law.

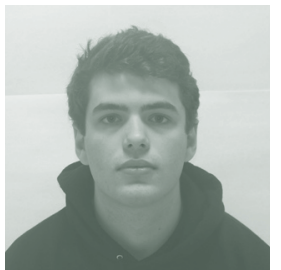

\section{HARRISON TUNE}

is a freshman in the College of Arts \& Sciences Honors Program, currently studying Biology on the Pre-Law track. His focus on Agency Law and Patent Law often spurs his interest in current events in the legal world such as the one discussed in his article. At Boston College, Harrison is involved in the Gabelli Presidential Scholars Program and is an Eco rep in the Residence Hall Administration. Most of his spare time, however, is spent practicing with the BC Fencing team, where he holds the position of Sabre. 


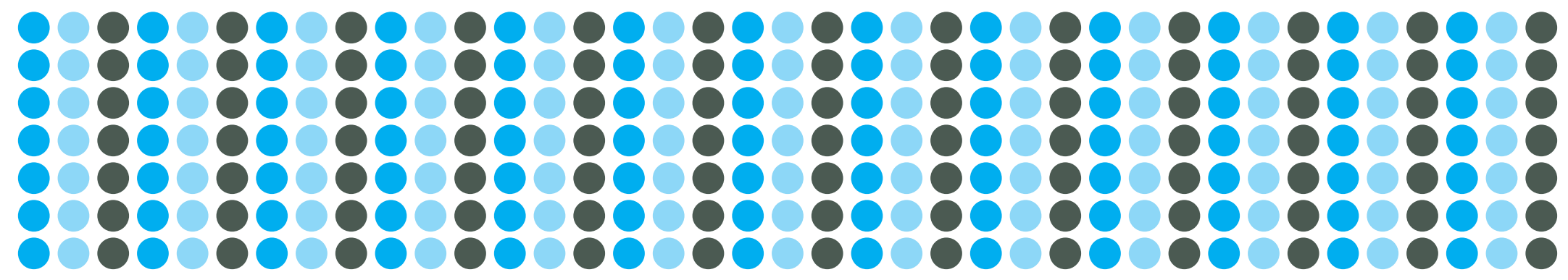

LIST OF ARTWORK

I W WRITER AYAD AKHTAR

(C) Wikimedia Commons

I 3 GROUND ZERO MOSQUE PROTESTOR

(C) Wikimedia Commons

I5 ISLAMIC CULTURAL CENTER IN MANHATTAN

(C) Wikimedia Commons

T\& DISGRACED PERFORMANCE STILL

(C) Geraint Lewis/Alamy

2.4 CHECHEN WOMEN

(C) Wikimedia Commons

36 CORN SHUCKING SONG

(C) Wikimedia Commons

38

SLAVES DANCE TO MUSIC OF BANJO

(C) Wikimedia Commons

5. MICHELLE OBAMA

(C) Wikimedia Commons

(1) lost title screen

(C) Wikimedia Commons

63

DEBRIS ON ROOFTOPS NEAR WORLD TRADE CENTER

(C) FEMA Photo Library

JOHN SHERMAN

(C) Library of Congress

7 I COMCAST AND TIME WARNER CABLE LOGOS

(C) Wikimedia Commons 